\title{
KÍSÉRLETI GYÁRTÁSHOZ KAPCSOLÓDÓ ADATVIZUALIZÁCIÓS FEJLESZTÉS A PURTÁR RENDSZERBEN
}

\author{
Hornyák Olivér \\ egyetemi docens, Miskolci Egyetem, Informatikai Intézet, Alkalmazott Informatikai Intézeti Tanszék \\ 3515 Miskolc, Miskolc-Egyetemváros, e-mail: oliver.hornyak@uni-miskolc.hu
}

\begin{abstract}
Absztrakt
A kísérleti gyártáshoz kapcsolódó kutatás-fejlesztési feladatokban nagy mennyiségü adat keletkezik. Ennek a valós idejü megjelenitése fontos követelmény a gyártástámogató informatikai rendszerekben. A nagy adathalmazokkal a felhasználók önmagában nem tudnak mit kezdeni. Azokból ki kell nyerni az információt, szürni és aggregálni kell. Jelen cikk áttekinti az elérhetö dashboardokat abból a célból, hogy a Miskolci Egyetem FIEK szervezeti egységében található PUR LABOR szoftverfejlesztési feladataihoz támpontot adjon. Bemutatjuk, hogyan lehet a kísérleti poliuretán hab gyártórendszer robotvezérlöjének naplófájljából kinyerni a receptúrára és kísérleti anyagok készletszintjét, és azok vizualizációját.
\end{abstract}

Kulcsszavak: szoftverfejlesztés, vizualizáció, dashboard

\section{Abstract}

Today's research and development tasks, manufacturing processes results huge amount of data. It is expedient to provide a real time graphical representation for the users. Information must be gained from data by filtering, aggregation, and other data processing functions. The goal of this paper to provide an overview on the available dashboard to be the base of selection in software engineering tasks. The development of shot data visualization technique is also presented. The paper presents the structure of the robot log file of the PUR Lab of FIEK department of University of Miskolc

Keywords: software engineering, visualization, dashboard

\section{Bevezetés}

Az adatok vizualizációjának fontos eleme a dashboard - magyarul talán müszerfal a legjobb fordítás.

A müszerfalak az adatokból kinyert információt matatják be. Ha folyamathoz kötődnek, akkor virtuális beavatkozó szervnek is tekinthetjük azokat. A jó dashboard jellemzői:

- könnyen olvasható,

- valós idejü,

- rendelkezik felhasználói interfésszel,

- grafikus,

- mutatja a historikus adatokat,

- mutatja a trendeket,

- mutatja a teljesítménymutatókat.

A dashboardok négy fajtáját szokták megkülönböztetni: stratégiai, analitikai, műveleti és informatív. A stratégiai müszerfal gyors áttekintést ad a döntéshozatal támogatására, igy jellemzően az üzleti folyamatokat monitorozza, előrejelzéseket ad. Az analitikai müszerfal felhasználói interakciót 
ad az adatokhoz, hogy tetszőleges finomsággal áttekinthessük azokat. A müveleti müszerfalak beavatkozást is lehetővé tesz, ezekhez eseményeket és eseménykezelőket lehet kötni. Az informatív dashboard pedig - a nevének megfelelően - az üzleti folyamatok mutatóit jeleníti meg, például eladási, marketing, erőforrások, termelés.

\subsection{Az alkalmazási terület}

A cél tehát az, hogy az adatokból nyerjük ki az információt. Az IoT világában [16] számos potenciális technika merül fel: felügyelt és felügyelet nélküli tanulás, deep learning, mesterséges intelligencia, okos (innovatív, kommunikációs és kiértékelő algoritmusokkal rendelkező) szenzorok.

Az adatkinyerés esetében az automatizált megoldások preferáltak a szakértői adatkinyeréssel [11] szemben, a kisebb költség, nagyobb pontosság és megbízhatóság, pontosabb anomália érzékelés elérése miatt. Az alábbi követelményeket lehet támasztani:

- informatív, azaz pontosan megjeleníti az adatokat, az adatok státuszát, a korrelációt az adatok között

- diagnosztikai, azaz megmutatja az anomáliákat és azok lehetséges forrását

- prediktív, azaz előre jelzi a szokásostól eltérő viselkedés bekövetkeztét,

- beavatkozó, azaz jelzi, hogy mikor kell közbelépni az anomália helyzetek elkerülése érdekében.

Az irodalmi vizsgálat alapján a tipikusan megcélzott alkalmazási területek:

- ember vezérelt/ember nélküli rendszerfelügyelet/karbantartás,

- távoli irányítás szolgáltatás.

Korábbi kutatási feladataimban dashboard alkalmazható:

- MES rendszerekben [14],

- ütemezési feladatokban [12][15]

- adatbányászati feladatokban.[11]

További áttekintést ad az alkalmazási területröl [17]. Az adatok egy része függetleníthető a folyamattól, lehet az kémiai adat, építőipari adat vagy éppen rendszerfelügyeleti adat.

Érdekes teoretikus megközelítés lehet magának a monitoring rendszernek a felügyelete: azaz annak az elörejelzése, hogy maga a szenzor mikor hibásodik meg (élettartam vizsgálat/felügyelet), vagy mért adatok validálása (például beszennyeződött szenzor).

\subsection{A kiválasztás szempontjai}

A Miskolci Egyetem FIEK szervezeti egységében található PUR labor [13] informatikai fejlesztéséhez kapcsolódó informatikai elvárásokat az alábbiakban fogalmazhatjuk meg:

- ingyenes rendszer. Alapkutatási feladatok esetén a büdzsé rendszerint nem teszi lehetővé a licencdíjak kitermelését, hiszen a kutatás önmagában nem bevételtermelő célú

- nyílt platform. A rendszernek lehetővé kell tennie, hogy a saját adattárházhoz kapcsolódjon, azon saját fejlesztésü algoritmusokat futtasson.

- lehetőség szerint adatbányászati algoritmusokat támogasson. A „szokásos” ismétlődő feladatokat ne kelljen újra kidolgozni benne

- többfajta informatikai eszközt támogasson. Legyen lehetőség széles informatikai környezetben való alkalmazása: változatos operációs rendszeren, hordozható / asztali / szerver számítógépen fusson, támogasson különböző képernyő méreteket és felbontásokat, 
- illeszthető legyen a már futó informatikai fejlesztésekhez

- legyen jól dokumentált,

- legyen a kinézete továbbfejleszthető, de adjon kidolgozott sablonokat is a gyors prototípus fejlesztéshez.

\section{2. Áttekintés}

Nagyon sok fizetős Dashboard szoftver van, a teljesség igénye nélkül:

Sisense, Periscope Data, iDashboards, Microsoft Power BI Pro, SAP Lumira, SAP Crystal Dashboard Design, Tableau Desktop, IBM Cognos Analytics, ThoughtSpot, GoodData, Datapine Business Intelligence, MicroStrategy, JReport, Knowi, Pyramid Analytics, Birst BI, WebFOCUS Platform, Dimensional Insight, SAP BusinessObjects BI, Domo, Oracle Business Intelligence, Qlik Sense Enterprise, Phocas BI Software, Dundas BI, Redash, Exago Business Intelligence, Yellowfin, AVORA, Cluvio, SAP Crystal Server, BIME Analytics, SAS Enterprise BI Server, BDB Platform, Zoomdata, DataHero, Looker, Izenda, InetSoft Style Intelligence, TARGIT Decision Suite, ClicData, DBxtra, AnswerRocket, Yurbi, Logi Analytics, Panorama Necto, Bright Gauge, Grow, Visual KPI, FusionCharts, ORBIT Enterprise, DataLion, Viur, Lumalytics, AppInsights, InfoCaptor Dashboard, InetSoft Style Scope, Easy Insight, Klipfolio, Geckoboard, Slemma, Bilbeo, Dashboard Builder, Panintelligence, OQLIS, Nucleus.

Vannak azonban ingyenes eszközök is, ezeknek az áttekintésével részletesen foglalkozom. Az 1. táblázat felsorolja a vizsgálatba bevont eszközöket és elérhetőségüket.

1. táblázat. A táblázat felirata

\begin{tabular}{|l|l|}
\hline Dashboard név & Elérhetöség \\
\hline Google Data Studio & https://datastudio.google.com/overview \\
\hline Cyfe & https:/www.cyfe.com/ \\
\hline QlikView Personal Edition & https:/www.qlik.com/us \\
\hline Databox & https://databox.com/ \\
\hline Cluvio & https://www.cluvio.com/ \\
\hline Kyubit Business Intelligence & https://www.kyubit.com/ \\
\hline Bilbeo & https://www.bilbeo.com/ \\
\hline Arcadia Data Instant & https://www.arcadiadata.com/ \\
\hline Bokeh & https://bokeh.org/ \\
\hline Plotly & https://plotly.com/dash/ \\
\hline
\end{tabular}

\subsection{Google Data Studio}

A Google Data Studio müködésének a lelke a Data Studio connector - ez az állandó komponens kapcsolja össze az adatot a megjelenítéssel. Kezeli az autentikációt, a felhasználói jogosultságokat, az 
adatok struktúráját. Az adatok csatlakoztatása után számos metrika rendelkezésre áll a számításokhoz, transzformációkhoz, vizualizációhoz. A riportok könnyedén elkészíthetők. Támogatja a csapatok együttmüködését, példákkal jól dokumentált. Vizuális szerkesztője van a müszerfalhoz, a riportokhoz. Teljesen testreszabható, stílusa tetszés szerint kidolgozható. A következő ábra egy képet mutat a galériából:

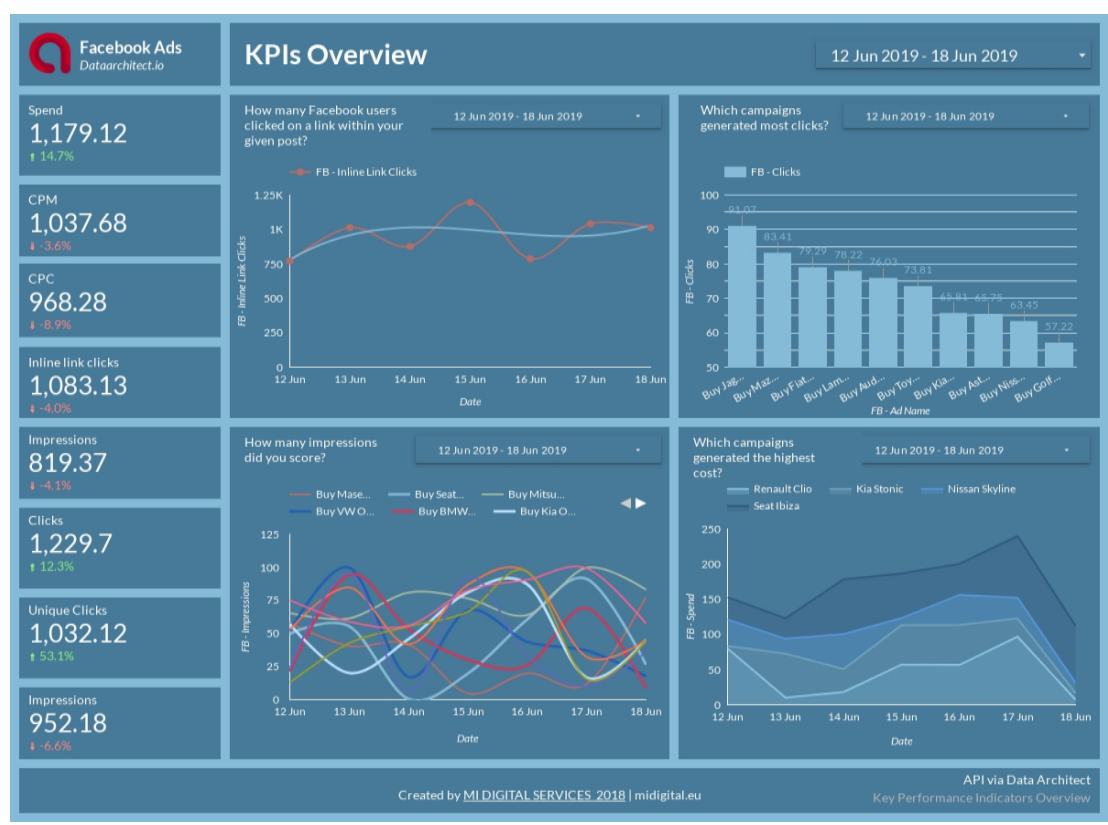

1. ábra. Google Data Studio [1]

\subsection{Cyfe}

A Cyfe felhő alapú szolgáltatást nyújt a dashboardok világában. Az üzleti intelligenciát megvalósítva analizál, átalakít és megjeleníti a különböző adatforrásból származó adatokat. Minden üzleti metrikát egy helyen kezel. A valós idejü a megjelenítés, az adatlekérés automatizálható. A kevésbé müszaki beállítottságúak is könnyen használhatják. Nagyon hasznos elöre definiált widgeteket ad, és azzal lehet monitorozni minden funkciót. Korlátlan darabszámú müszerfal, 30 napra visszamenőleg kezelhető adatok kezelése és elforgatható kijelző támogatása jellemzi.

\subsection{Qlik}

A Qlik üzleti intelligenciáját a felhasználói igények vezérlik. A QlikView az adatokban rejlö összefüggésekre mutat rá, a kapcsolatokat vizuális módon ábrázolja. Kezeli a komplex, több adatforrásból álló bemenetet is. A QlikView Personal Edition termékcsoport ingyenes. A partner licensz nélkül is használható tagja asztali gépen fut. Azonban üzleti felhasználásra az ingyenes változat nem alkalmazható. Előnyös, ha az adatok több forrásból származnak, támogatja a csoportos együtt dolgozást, a vizualizációt, a keresést. Kiegészíthető interaktív alkalmazásokkal, analitikával. Mobil eszközökről is elérhető. Analizál és elment adatokat. Az ingyenes változatban nem oszthatunk meg másik felhasználóval fájlt, nem importálhatunk be teljes komponens-elrendezést, adattáblát, objektumot, biztonsági beállítást. 


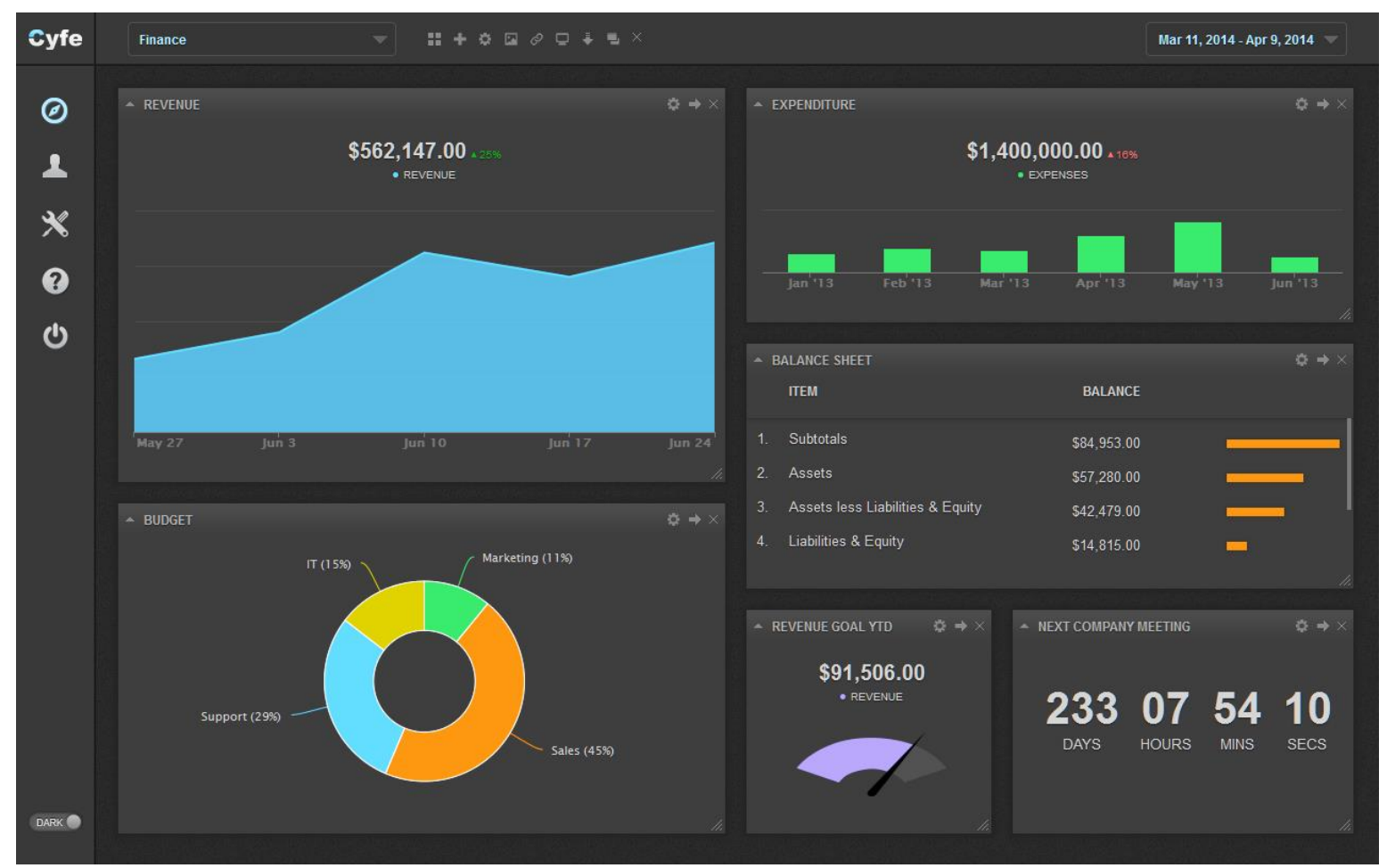

2. ábra. Cyfe [2]

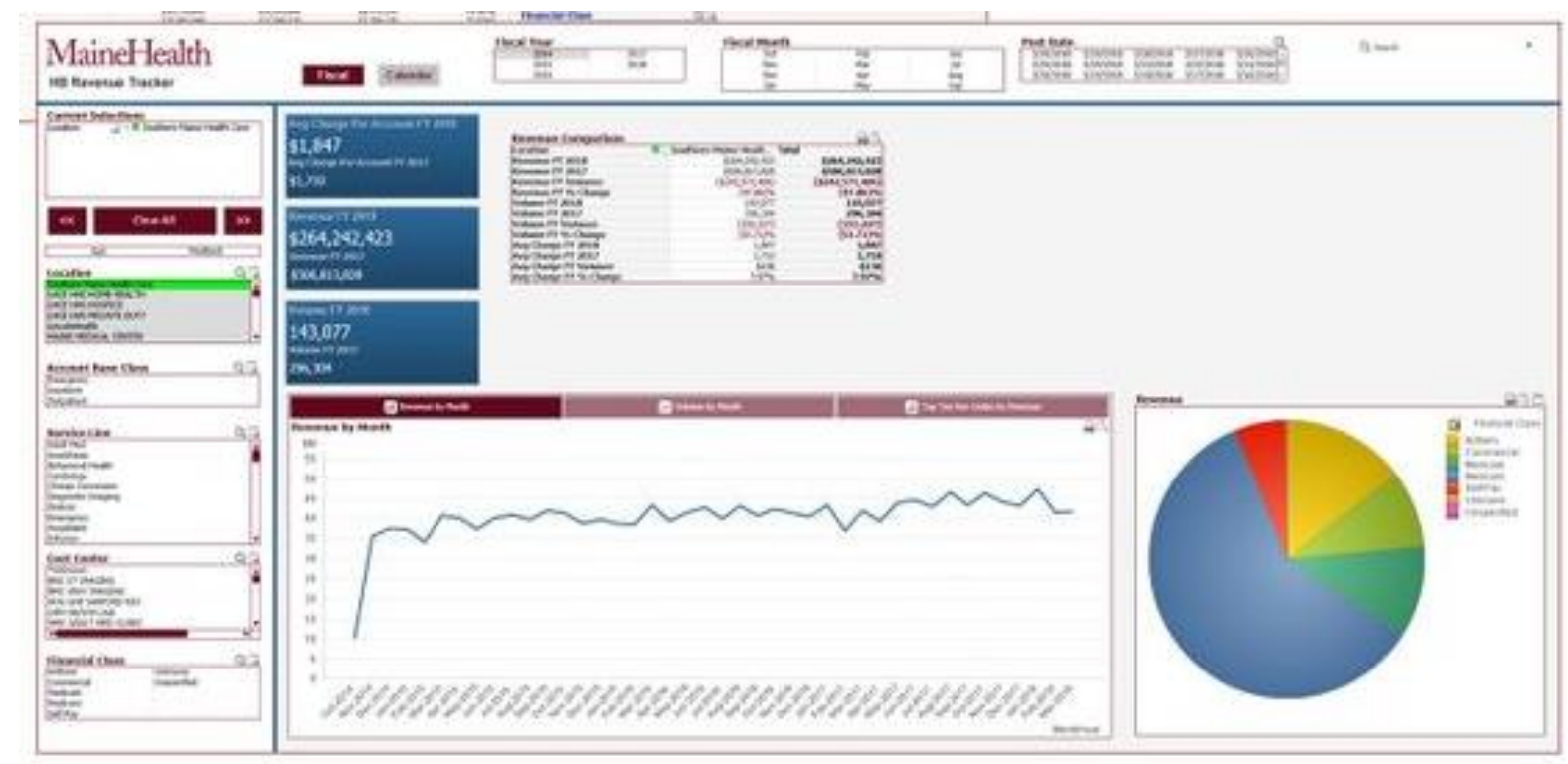

3. ábra. Qlik [3] 


\subsection{Cluvio}

A Cluvio is a felhőben fut és a startupokat, valamint az adat-vezérelt fejlesztői csapatokat célozza meg. A felhasználó SQL és R nyelvü lekérdezéseket állíthat össze. Az eredmény látványos, interaktív müszerfal lesz, amely az egész cég igényeit kielégíti. Gazdag módon jeleníti meg az adatokban megbúvó információt. A teljesítmény-mutatók mellett minden adat interaktív és valós idejü. A felhasználók riasztásokat köthetnek az adatokhoz. Gondosan figyel az adatvédelemre, banki szintủ a biztonság, a müszerfalak megoszthatók a kollégákkal - akár emailben is. Az üzleti változat ára borsos.

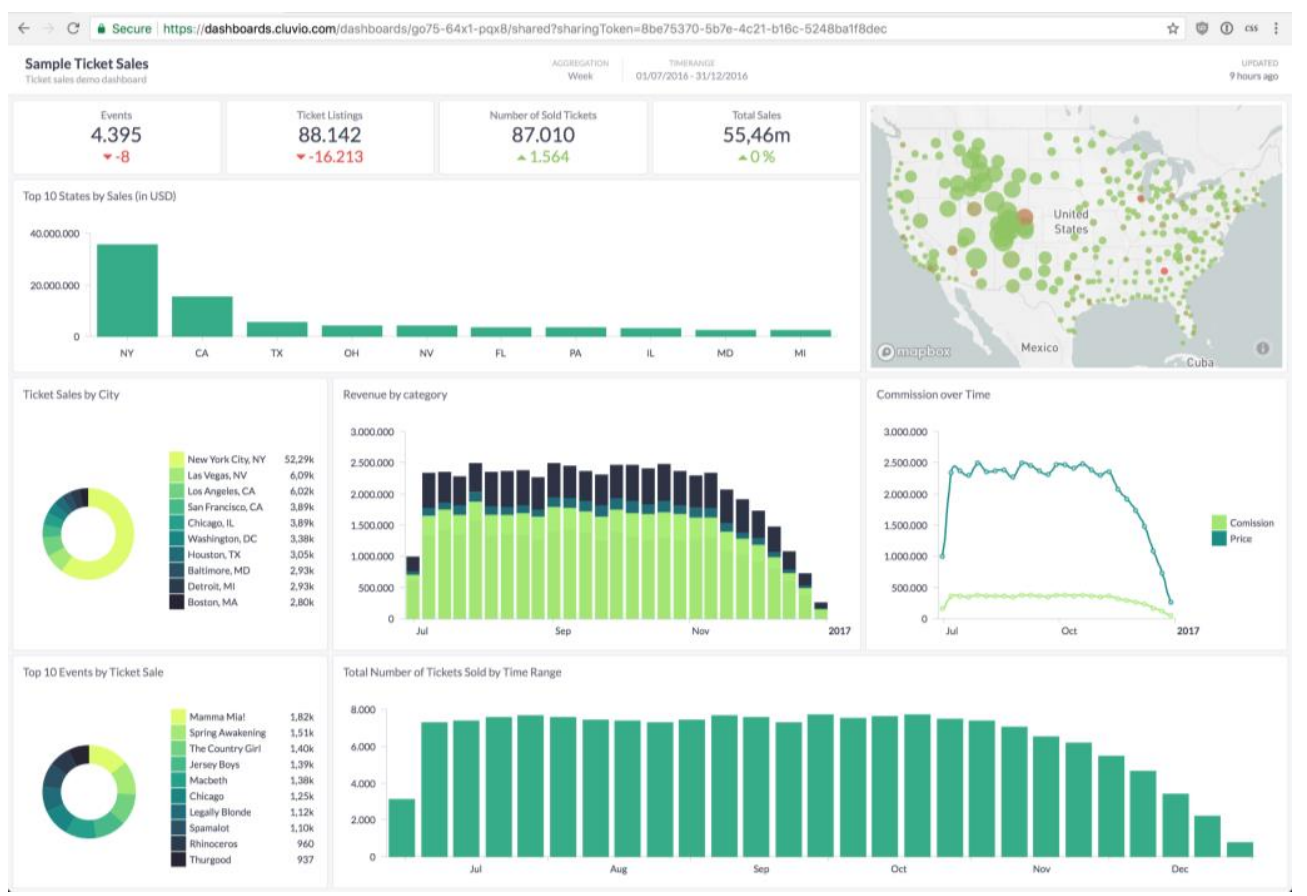

4. ábra. Cluvio [4]

\subsection{Databox}

A Databox egy olyan üzleti analitikai eszköz, amellyel megérthetők az üzleti folyamatok. A teljesítménymutatók munkafüzetekböl, adatbázisokból egy helyen elkészíthetök. A mobil alkalmazás az intuitív felületével rugalmas hozzáférést biztosít. Jól definiálható adatkapcsolaton nyugszik és erős adatvédelmet ad. Valós időben frissül. A Designer segítségével, a lekérdezés varázslóval könnyen kezelhető jó riportokat nyújt.

\subsection{Kyubit}

A Kyubit Business Intelligence a Microsoft BI környezetébe illeszkedik. OLAP alapú analízist és böngészős megjelenítést ad. A müszerfal kiválóan alkalmas a metrikák megjelenítésére, támogatja a csapatok munkáját. Exportálhatunk PDF és Excel formátumba. Felskálázható a nagyvállalati igényekig is $\mathrm{Az}$ adatmodell kiterjedt. Modern, Big-data szemléletü. A müszerfal interaktív, elérhető desktop és mobil eszközröl is. Támogatja a többnyelvü fejlesztést. 


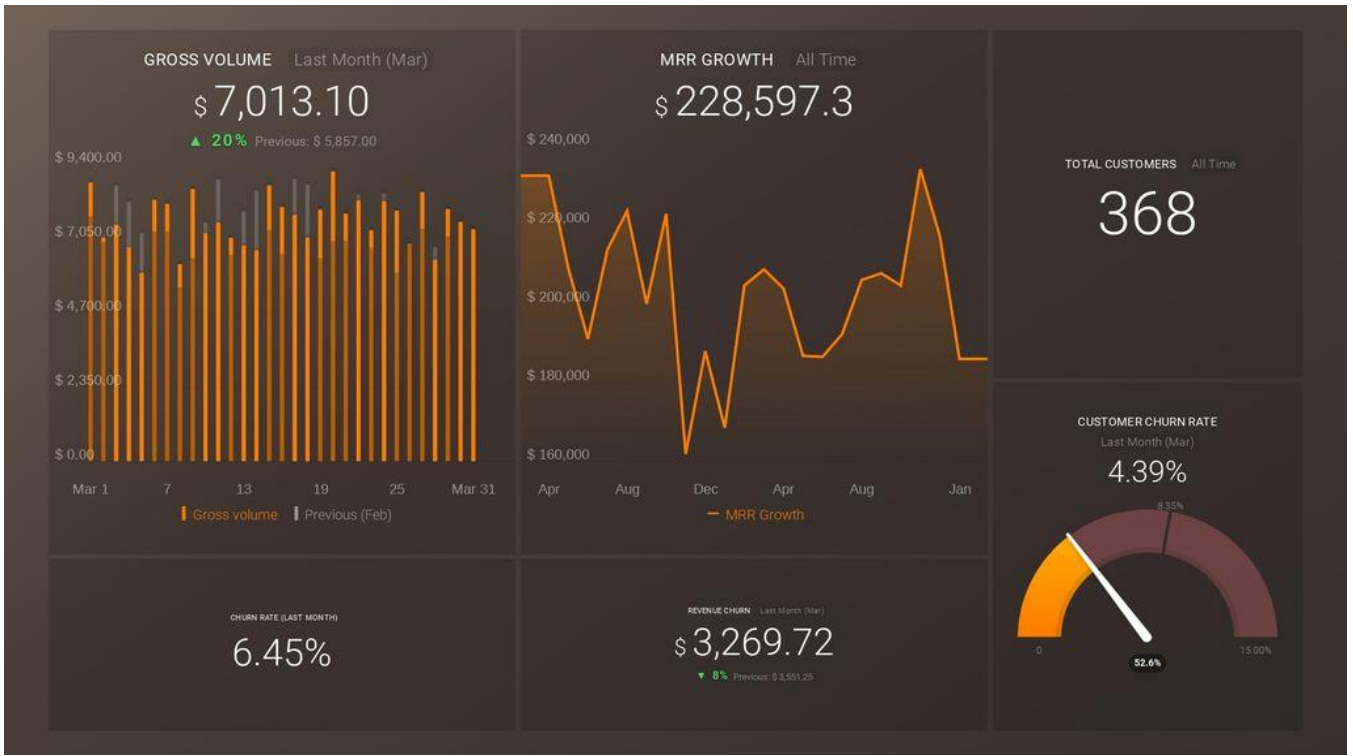

5. ábra. Databox [5]

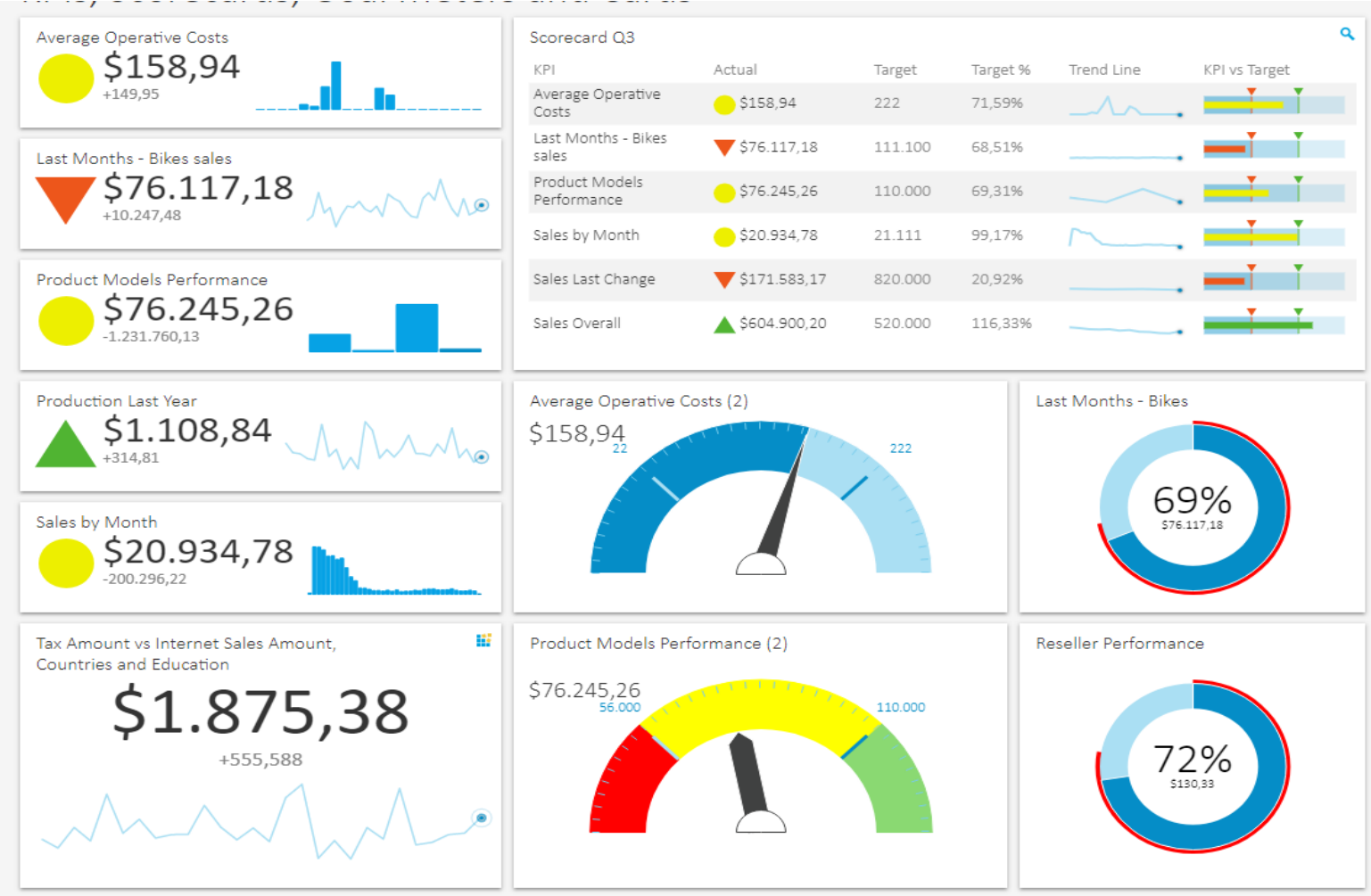

6. ábra. Kyubit Business Intelligence [6] 


\subsection{Bilbeo}

A Bilbeo web alapú müszerfal. Elsősorban a teljesítménymutatók megjelenítésére koncentrál, így a menedzsmentet célozza meg a funkcionalitásával. Mind kis, mind nagy adathalmazokkal hatékonyan müködik. A müszerfal intuitív, adatbányász technikákat kínál, és azokat könnyen kezelhetővé teszi. „Okos riasztás” funkciója van, a riportok testre szabhatók. Csoportmunkára alkalmassá teszi a felhasználó menedzsmentje.

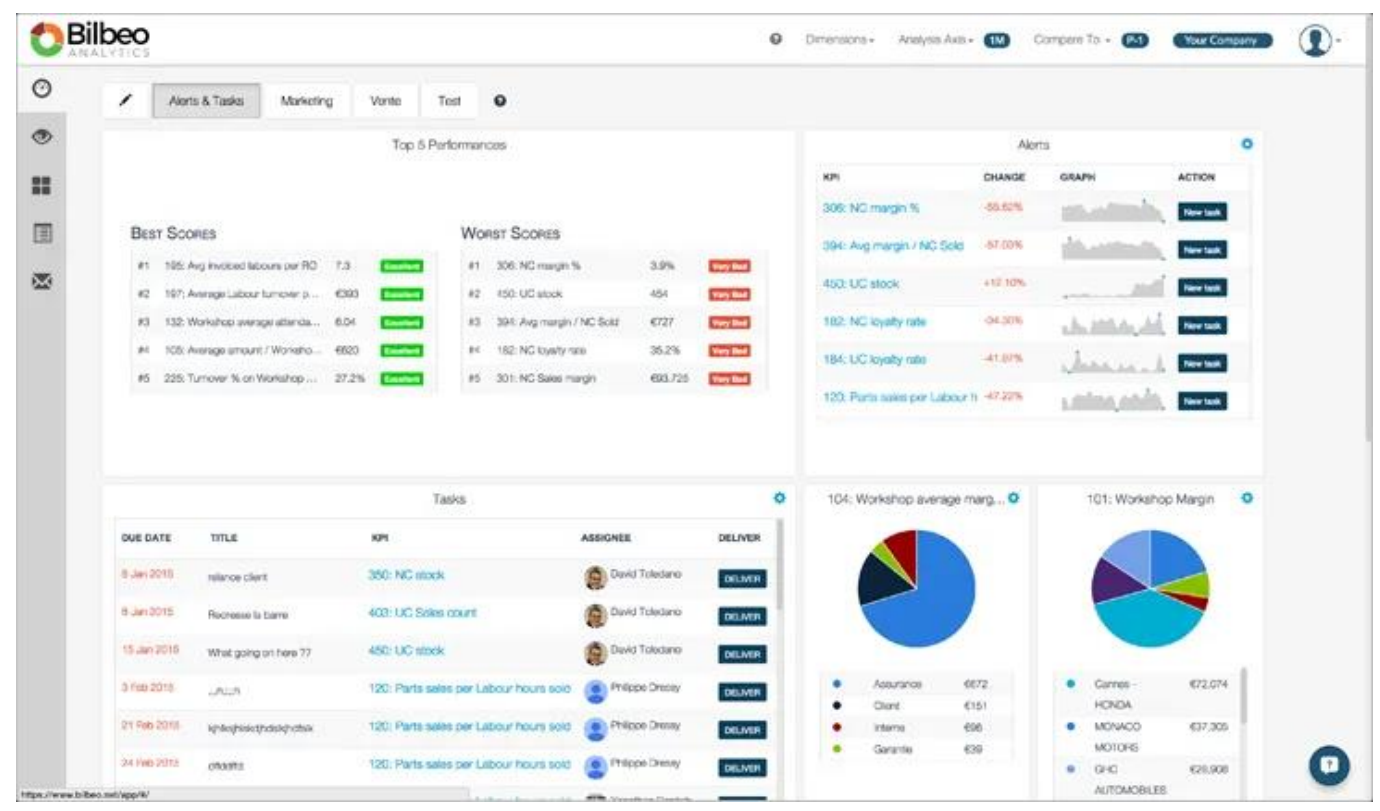

7. ábra. Bilbeo [7]

\subsection{Arcadia}

Az Arcadia Data Instant nagyon gyors analitikát végez, az üzleti intelligencia futtatása adatklasztereken történik, így a teljesítménye jól skálázható. Az fejlesztés lépcsői és főbb funkciói: adatkapcsolat létrehozása, felfedezése, modellezése, vizualizációja, interakció, menedzsment, skálázás, optimalizáció, publikálás és megosztás.

\subsection{Bokeh}

A Bokeh az API függvényei miatt vált a fejlesztők és az adattudósok kedvencévé. Letisztult, könnyen érthető megjelenítéssel müködik. Egyszerü grid layoutot ad, de templétekbe is beágyazhatók az interaktív diagrammok. Rugalmas, interaktív, megosztható, termelékeny és nyílt forráskódú.

\subsection{Plotly}

A Plotly web alalapú analitikai alkalmazás, Javascript program nélkül. Testre szabható a CSS erejével. Az interaktív felhasználói felületnek köszönhetően egyszerü a menük, grafikonok, csúszkák megjelenítése, az analitikai kód beágyazása, adatnézeti képek kidolgozása. 


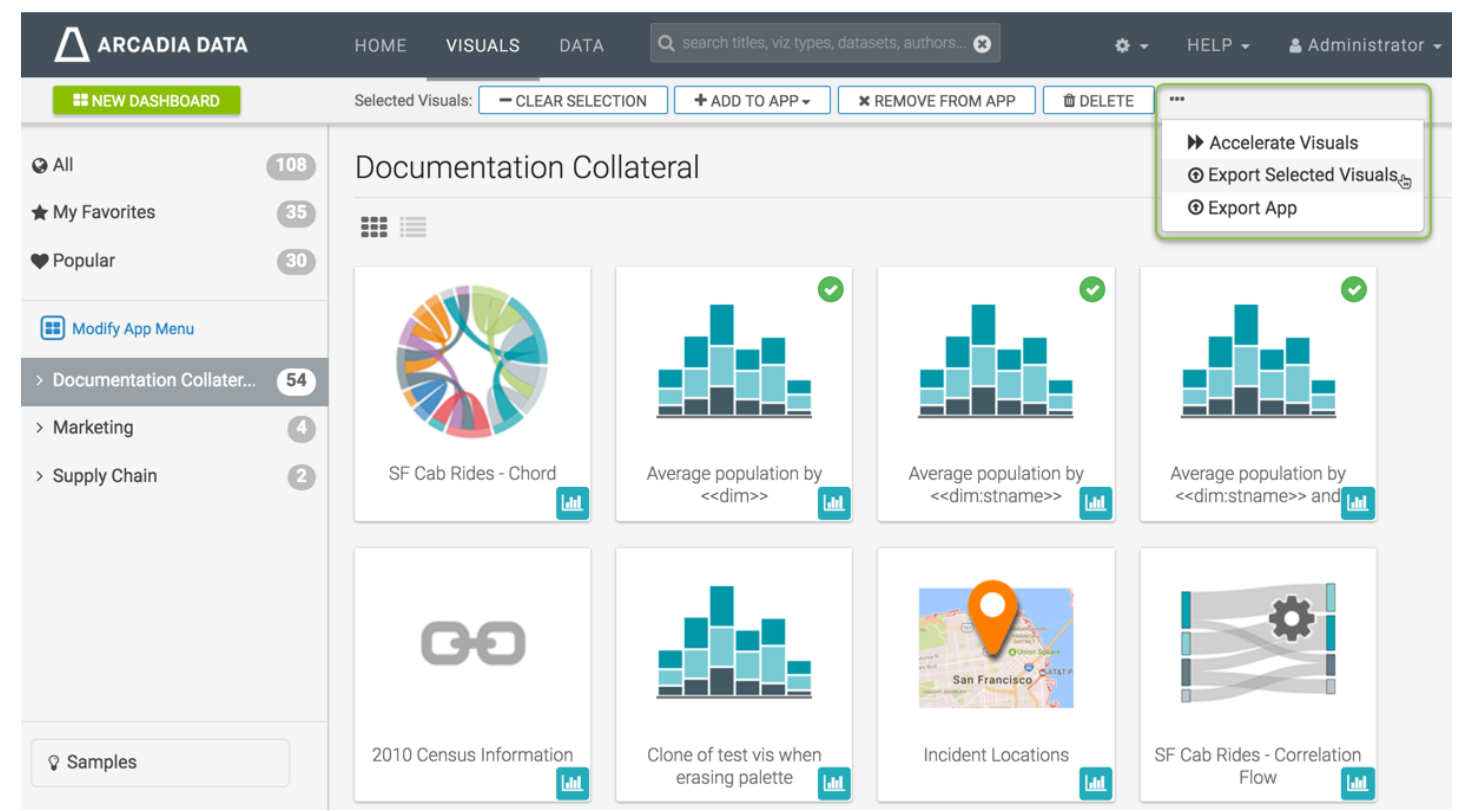

8. ábra. Arcadia [8]

\begin{tabular}{|c|c|c|c|c|}
\hline ancolven & 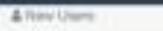 & 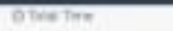 & $4 \tan 6000$ & 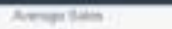 \\
\hline 11200 & 350 & 5.6 & 27300 & 8700 \\
\hline - is niminie the & 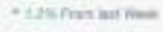 & Fess finmiarkm & - essivinime & 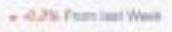 \\
\hline
\end{tabular}

Network Activities Thife per aw
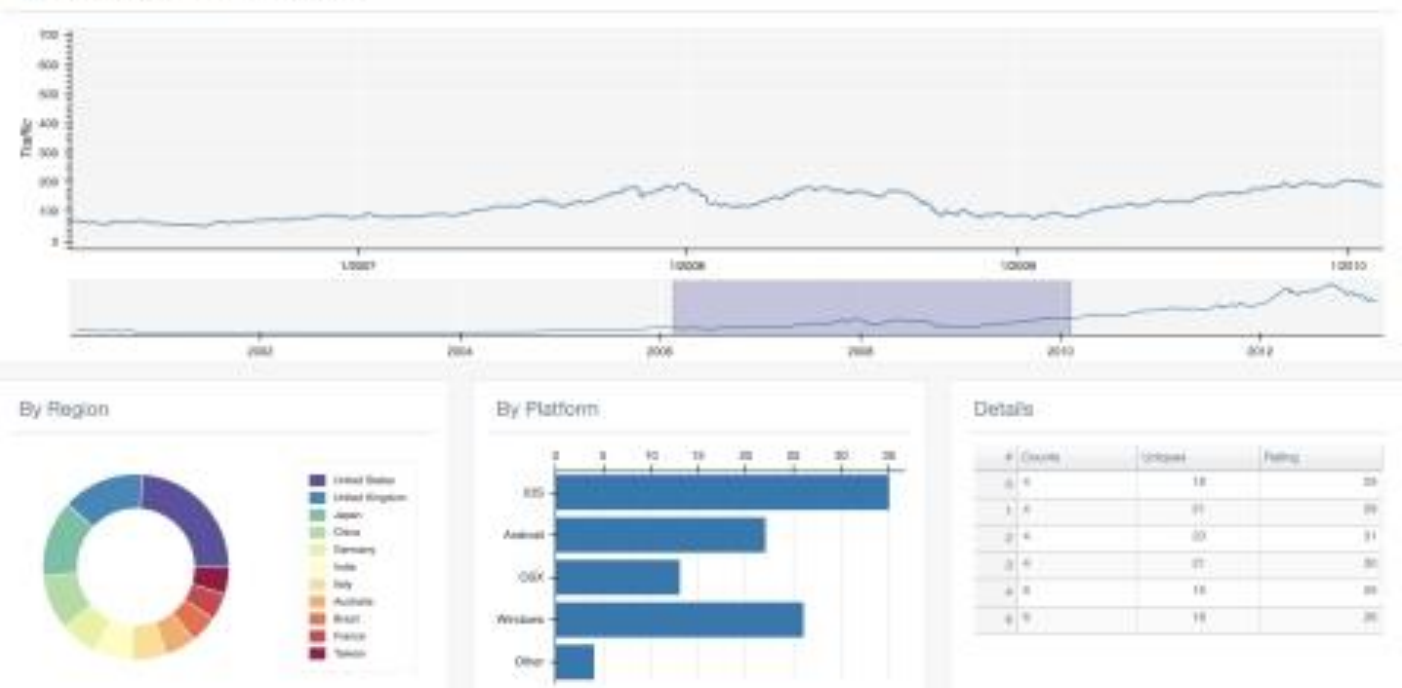

9. ábra. Bokeh[9] 


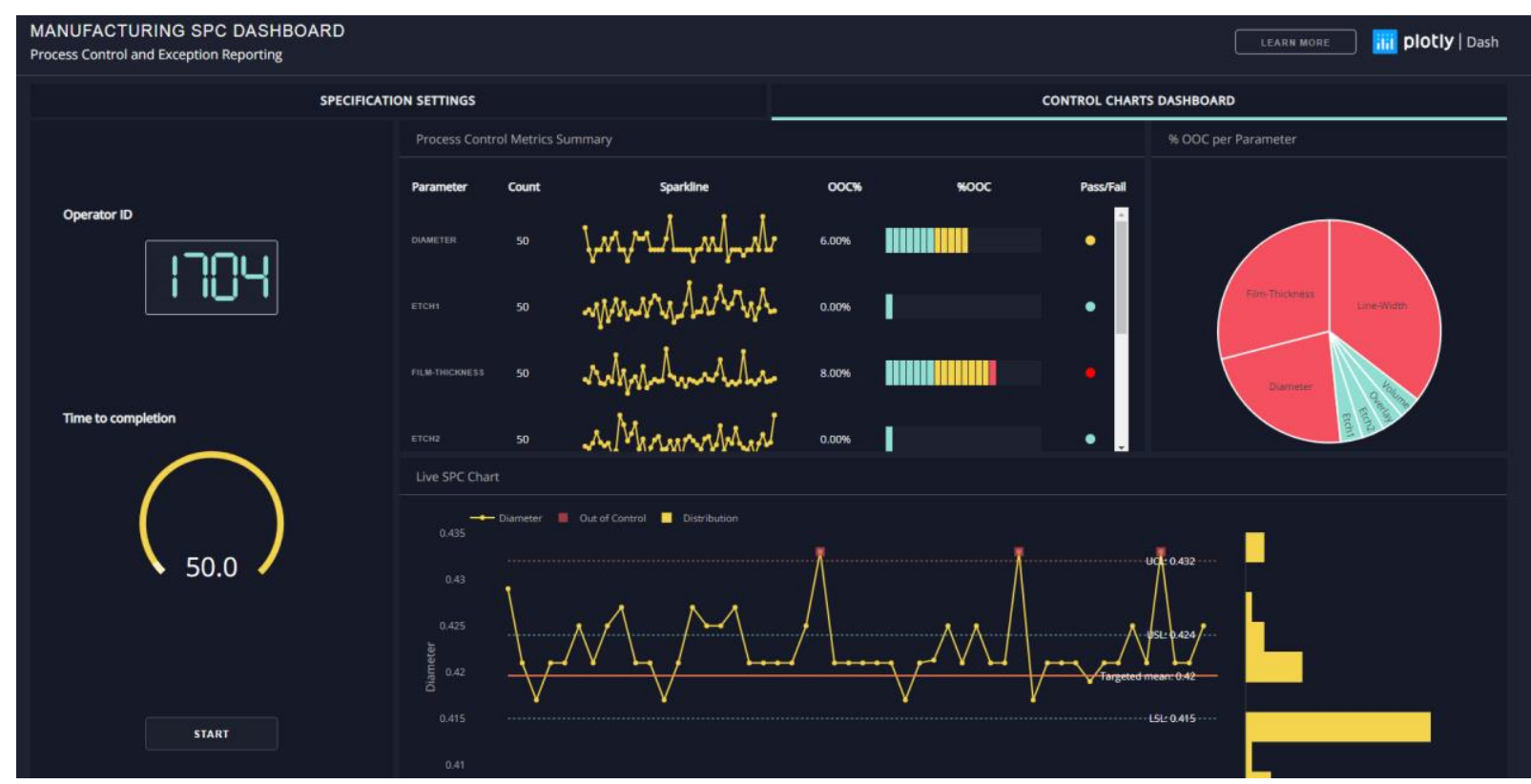

10. ábra. Plotly [10]

\section{PUR Labor integráció}

A FIEK projekt keretében kialakított robot labor az elmúlt hónapokban került átadásra. A következő ábrán a PUR Robot labor látható, középen a kísérleti gyártósor robotjával. A második képen hat tartály látható, a kísérletek során az ezekben tárolt alapanyagokból gyárt a labor poliuretán (PUR) habot. Az anyagok keverési aránya, a robot pályabejárási stratégiája az a PUR receptura, amelyekkel aztán további anyagvizsgálati méréseket végeznek. A receptura tehát fontos kísérleti adat, amelyet ki kell nyerni. A tartályok szintjének grafikus megjelenítése pedig a kísérletezés egyik fontos támogató feladata.

A kísérletezés menete:

- A K1 - K6 tartályok folyamatosan feltöltésre kerülnek PUR alap és adalékanyagokkal.

- A mérés és kísérlettervezés során megtervezik a szerszám geometria alapján a robot mozgását. A szükséges méréseket, a technológiai paramétereket: például a forma hőmérsékletét, a gyársási időket, az anyagáramlási sebességet.

- A gyártási program beállításra, feltöltésre kerül a robot PLC vezérlésbe. Ez jelenleg kézzel történik, a gyártóüzem és a labor között nincs hálózati kapcsolat, ami egyben az integráció legnagyobb nehézsége.

- A gyártás után a termékek a késztermék raktárba kerülnek és előkészítésük után elvégzik rajtuk a szükséges méréseket, valamint a mérések kiértékelését.

- Tetszőleges időközönként, általában napi gyakorisággal letöltik a robot PLC naplófájlt (shot data), amely CVS formátumban tartalmazza a termék gyártása során keletkező, előre definiált paramétereket. 

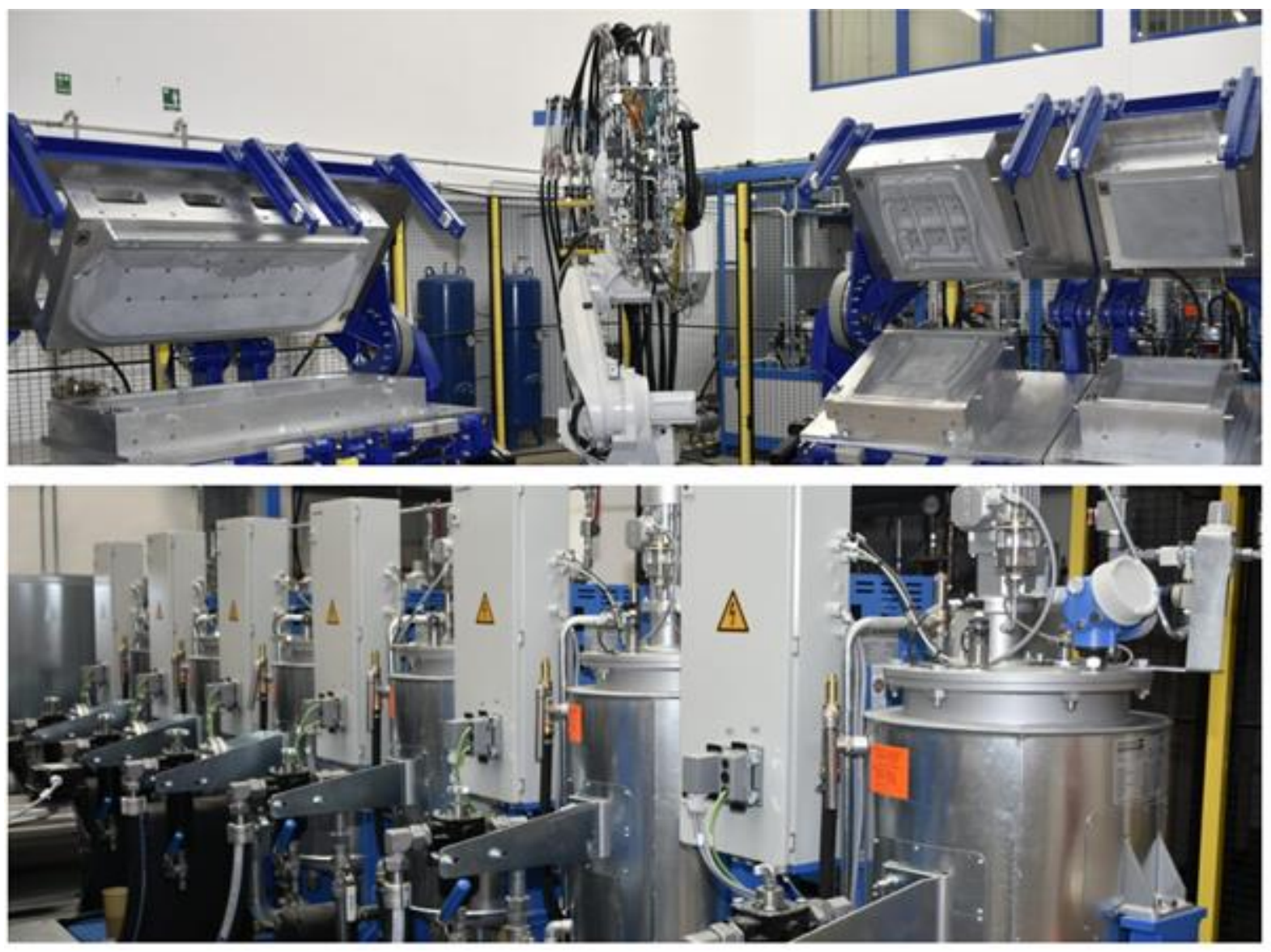

11. ábra. a) PUR robot b) K1-K6 tartályok

\subsection{Shot Data felépítése}

A robot és gyártásvezérlő PLC a „lövések” adatait lementi, az adat pendrive segítségével lementhető. Vizsgáljuk meg a tartalmát: a következő táblázat az egyes oszlopok nevét, mértékegységét és egy lövés adatait mintaként tartalmazza.

Az első 13 oszlop általános információkat tárol a gyártásról. Az első oszlop egy egyedi index, amely automatikusan növekszik minden használatkor. Feldolgozásával általános összegző információt kapunk a felhasznált anyag mennyiségéről, a gyártási időről. A „wetshot” true/false érték azt jelzi, hogy a gyártás tényleges megtörtént-e. Ez a kapcsoló, a későbbiekben szürőfeltételként lesz felhasználva. Összesen hét csoportot különböztetünk meg, az általános információk mellett a K1-K6 alapanyagok információit is lementjük. A csoport utolsó oszlopa mutatja, hogy hány \%-ban van megtöltve a tartály. Ezt az információt felhasználjuk a PURTÁR dashboard-on. 


\begin{tabular}{|l|l|l|}
\hline Oszlop név & Mértékegység & Mintaadat \\
\hline Index & {$[-]$} & 568 \\
\hline date/time & {$[\mathrm{DD}: \mathrm{MM}: \mathrm{YYYY}$} & 11.03 .2020 \\
$\mathrm{hh}: \mathrm{mm}: \mathrm{ss}]$ & $13: 01: 26$ \\
\hline mixhead No. & {$[-]$} & 1 \\
\hline dosing package No. & {$[-]$} & 50 \\
\hline dosing package name & {$[-]$} & \\
\hline last shot No. & {$[-]$} & 1 \\
\hline recipe No. & {$[-]$} & 1 \\
\hline recipe name & {$[-]$} & $\mathrm{R} 1$ \\
\hline nominal dosing time & {$[\mathrm{s}]$} & 3,68 \\
\hline actual dosing time & {$[\mathrm{s}]$} & 3,68 \\
\hline nominal total weight & {$[\mathrm{g}]$} & 1004,64 \\
\hline actual total weight & {$[\mathrm{g}]$} & 998,2271 \\
\hline wetshot & {$[-]$} & True \\
\hline nominal tank temperature $\mathrm{K} 1$ & {$\left[{ }^{\circ} \mathrm{C}\right]$} & 0 \\
\hline actual tank temperature K1 & {$\left[{ }^{\circ} \mathrm{C}\right]$} & 0 \\
\hline nominal flow rate K1 & {$[\mathrm{g} / \mathrm{s}]$} & 0 \\
\hline actual flow rate K1 & {$[\mathrm{g} / \mathrm{s}]$} & 0 \\
\hline nominal ratio K1 & {$[-]$} & 0 \\
\hline actual ratio K1 & {$[-]$} & 0 \\
\hline nominal mixhead pressure K1 & {$[\mathrm{bar}]$} & 0 \\
\hline $\begin{array}{l}\text { actual mixhead pressure prerun } \\
\text { K1 }\end{array}$ & {$[\mathrm{bar}]$} & 0 \\
\hline actual mixhead pressure dosing $\mathbf{K 1}$ & {$[\mathrm{bar}]$} & 0 \\
\hline nominal mixhead temperature $\mathbf{K} 1$ & {$\left[{ }^{\circ} \mathrm{C}\right]$} & 0 \\
\hline actual mixhead temperature K1 & {$\left[{ }^{\circ} \mathrm{C}\right]$} & 55,03472 \\
\hline nominal tank level K1 & {$[\%]$} & \\
\hline actual tank level K1 & {$[\%]$} & 0 \\
\hline & & 0 \\
\hline
\end{tabular}

\section{A tartályok töltöttségi szintjének megjelenítése}

A Shot Data naplófájl betöltését és feldolgozását implementáltuk a PURTÁR rendszerbe. A dashboard vezérlök megjelenítéshez a Plotly csomagot használtuk. Létrehoztunk egy Shot Data menüpontot, amely dashboard kezdőlapjaként funkcionál. Az alábbi ábrán ennek a megjelenítését láthatjuk. A tartályszinteket megjelenítő rész kétféle nézettel rendelkezik: „mérőmüszer” nézet és oszlopdiagram nézet. A jobb oldali részben a 6 tartály töltöttségi szintje látható az idö függvényében - napi, heti, havi, féléves és éves bontásban. 


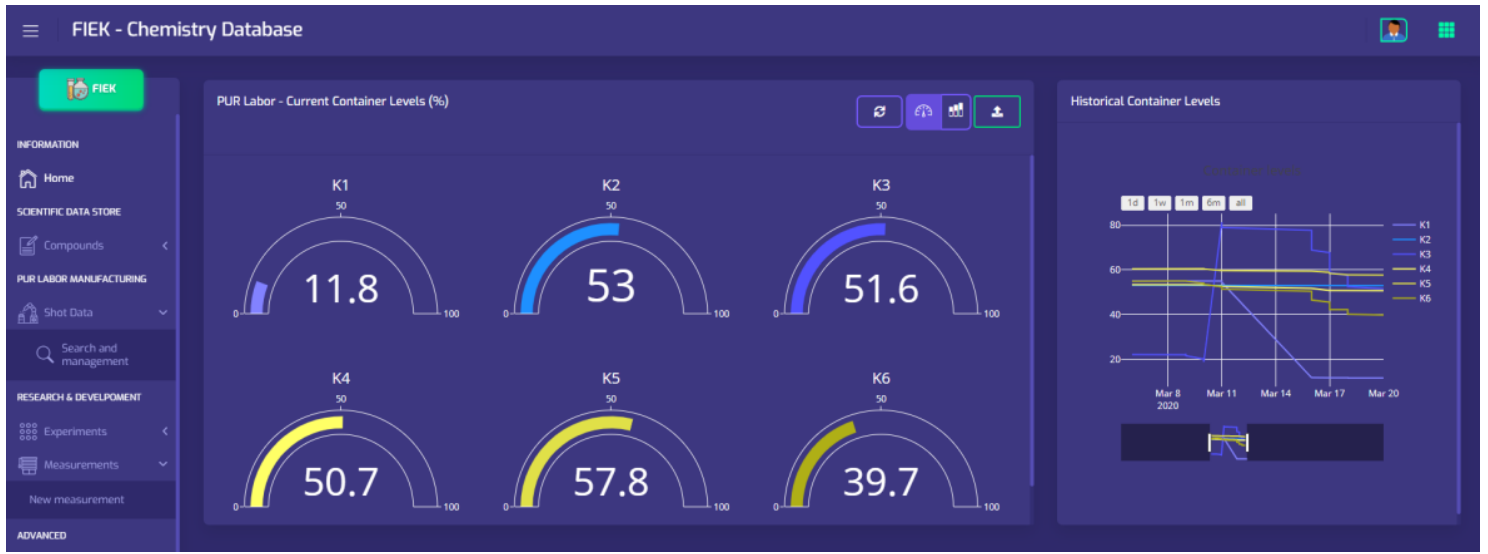

12. ábra. PURTÁR dashboard gauge nézete

Az oszlopdiagram nézet szemlétesen mutatja az egyes tartályok töltöttségi szintjét. A színek csoportjai szemléletesen mutatják a Poliol és az MDI típusú alapanyagokat. A következő ábra erre mutat példát:

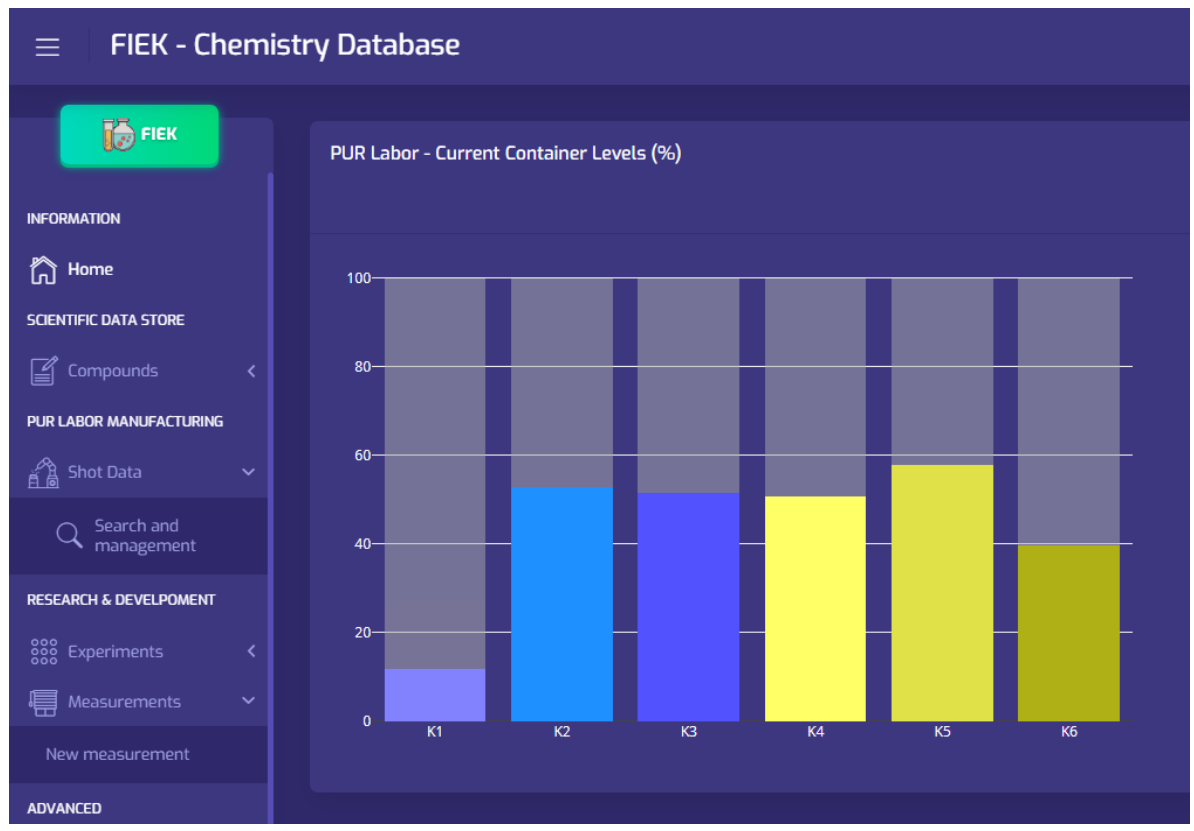

13. ábra. PURTÁR dashboard barchart nézete

\subsection{Shot data listázása és szürése}

A shot data menedzsmenthez hozzátartozik a keresés és részletes adatmegjelenítés funkció. A menüben a kereséssel lekérdezhető az összes rendelkezésre álló adat, ahol a nagy mennyiség miatt az adatok időrendben visszafelé jelennek meg A ,wet shots only” kapcsoló csak azokat az eredményeket szüri, amelyek nem tartoznak a tesztelési kategóriába. Az úgynevezett száraz teszt esetén ugyanis a robot bejárja a pályagörbéjét, de PUR habot nem készít. 


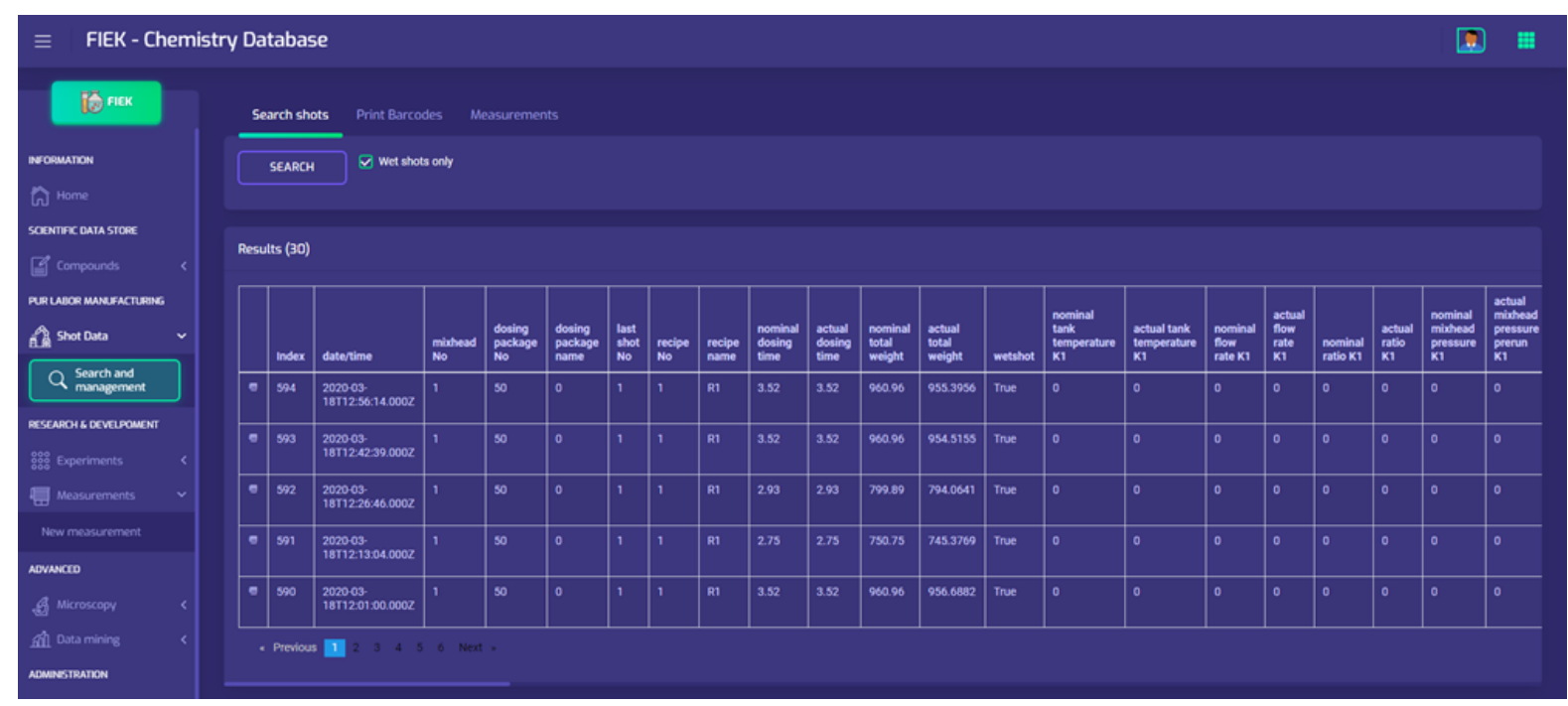

14. ábra. PURTÁR Shot Data listázás és szürés

\subsection{PURTÁR integrációs eredmények}

Az adatvizualizáció mellett a következő integrációs feladatokat is implementáltuk és a rendszerben elérhetővé tettük:

- Lehetőség nyílik alapértelmezett mérések definiálására a shot-okhoz. Ebben az egyszerü adatmodellben abból indulunk ki, hogy a gyártmány ID-je tudja azonosítani a rajta elvégzendő méréseket.

- A mérések dokumentálása: az újonnan beépített ID-ket hasonló módon lehet felhasználni, mint a korábbi receptúra azonosítókat.

- Az utóbbi hónap megbeszélései rávilágítottak, hogy az új adatok integrációja sokkal messzebbre vezet, mint a korábbi struktúra. Jelen dokumentum még nem tartalmazza ezeket az újításokat.

\section{5. Összefoglalás}

A cikkben áttekintettük az adatvizualizációs szoftverkomponenseket. Az áttekintés célja sz volt, hogy a PURTÁR [12] rendszerben a molekula adatok és a mérési eredmények vizualizációjához megfelelő eszközt kiválasszuk. A kutatómunka következő lépése a kiválasztott Plotly dashboard integrálása a PURTÁR rendszerbe volt. Bemutatta a cikk azt az eljárást, amely a shot data feldolgozása után vizualizálja a tartály szinteket, és lementi a kísérleti adatokat. Ez a további kísérletek elvégzésének hasznos kiindulópontja lehet.

\section{Köszönetnyilvánítás}

A kutató munka az Európai Unió és a magyar állam támogatásával, az Európai Regionális Fejlesztési Alap társfinanszírozásával, a GINOP-2.3.4-15-2016-00004 projekt keretében valósult meg, a felsőoktatás és az ipar együttmüködésének elősegítése céljából. 


\section{Irodalom}

[1] https://datastudio.google.com/open/1T6SuN5xHtCqGRX6mXL8rttKEa8IvCf_H

[2] https://i.pinimg.com/originals/4f/93/41/4f9341ff889d9473c560bee578f64c87.png

[3] https://cyjdu72974.i.lithium.com/t5/image/serverpage/imageid/24930i3B4EA430F39A662A/image-size/large? $\mathrm{v}=1.0 \& \mathrm{px}=999$

[4] https://www.cluvio.com/images/screenshot/sample-dashboard-2.png

[5] https://s3.us-east-1.amazonaws.com/dashboardsnapshots/l/rfmeijqlrmm.jpg

[6] https://www.kyubit.com/Images/kpi-dashboard/kpi-dashboard-final.png

[7] https://i0.wp.com/www.bilbeo.com/wp-content/uploads/dashboards.png?w=733

[8] http://docs.arcadiadata.com/4.1.0.0/img/export-vis.png

[9] https://bokeh.org/img/dashboard.png

[10] https://dash-gallery.plotly.host/dash-manufacture-spc-dashboard/

[11] Szabó, N. P., Nehéz, K., Hornyák, O., Piller, I., Deák, Cs., Hanzelik, P., Kutasi, Cs., Ott, K.: Cluster analysis of core measurements using heterogeneous data sources: An application to complex Miocene reservoirs. Journal of Petroleum Science and Engineering, pp. 575-585, 2019 https://doi.org/10.1016/j.petrol.2019.03.067

[12] Hornyák, O: Virtuális poliuretán tárház informatikai rendszer fejlesztése, Müszaki tudomány az Észak-kelet Magyarországi Régióban 2019 konferencia előadásai, (2019) pp. 137-140. 